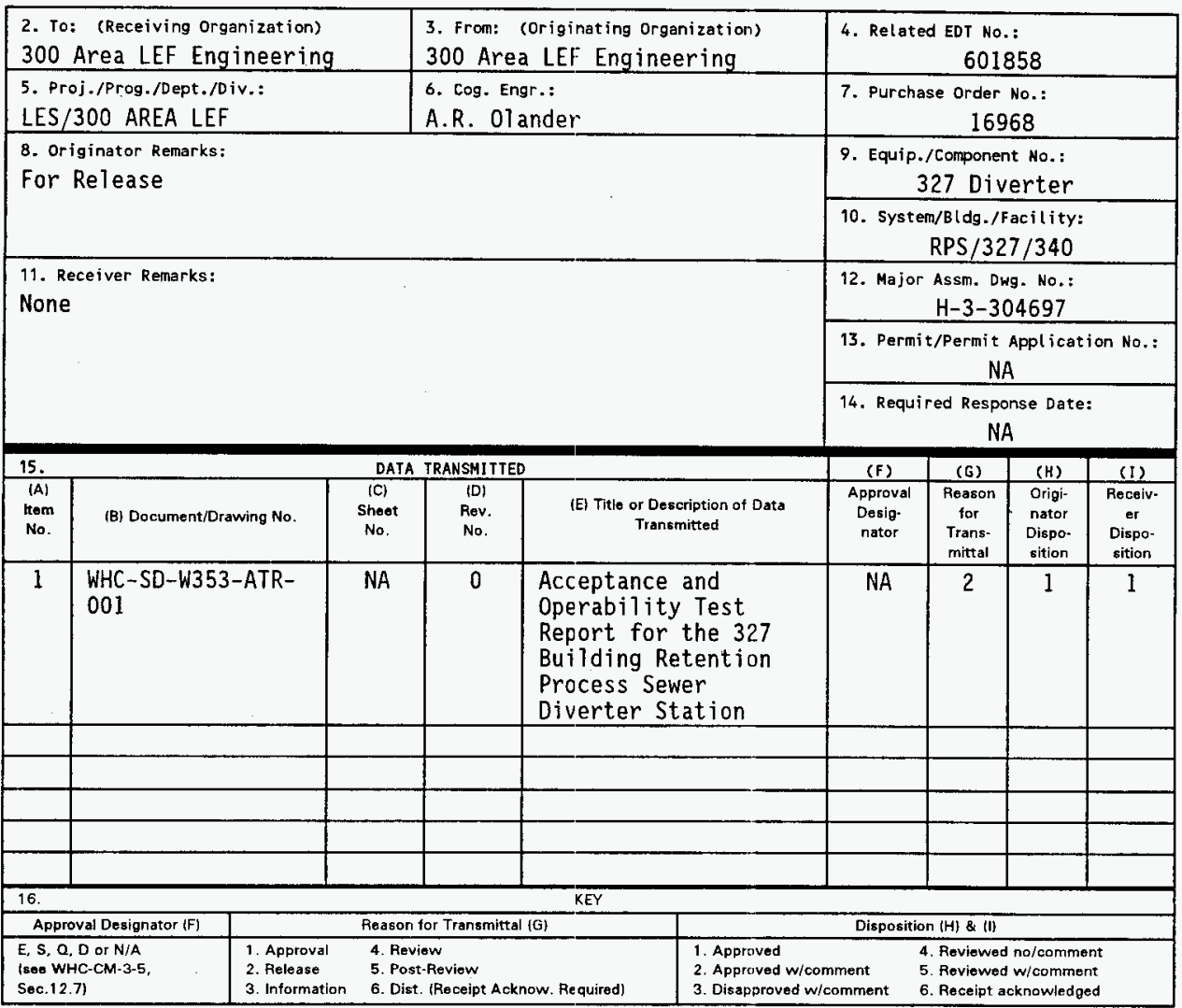

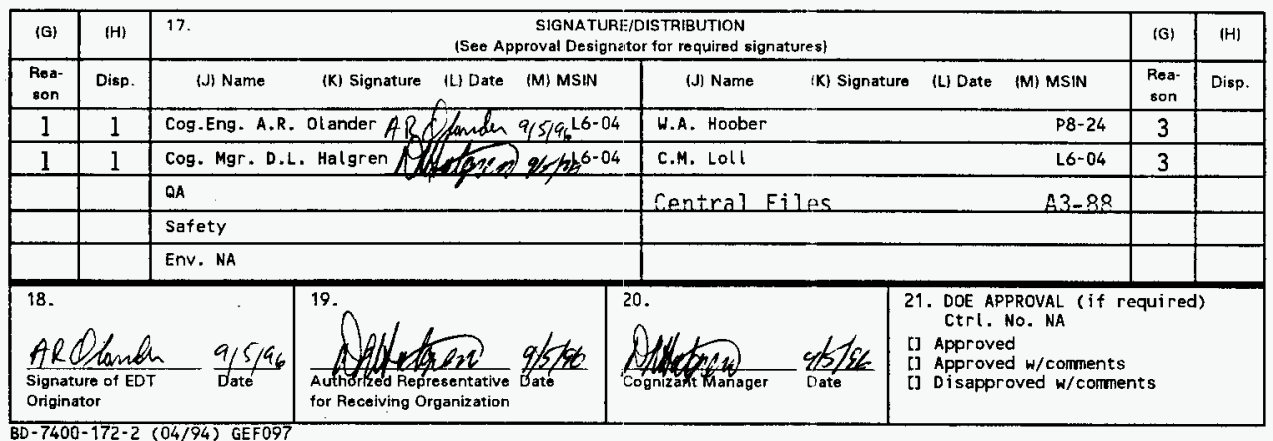




\title{
ACCEPTANCE AND OPERABILITY TEST REPORT FOR THE 327 BUILDING RETENTION PROCESS SEWER DIVERTER STATION
}

\author{
A.R. 01 ander \\ Westinghouse Hanford Company, Richland, WA 99352 \\ U.S. Department of Energy Contract DE-AC06-87RL10930 \\ EDT : 618088 \\ Org Code: 86730 \\ B\&R Code: $39 E W 31302$ \\ UC: 506 \\ Charge Code: A234C \\ Total Pages: 24 \\ EW 3/30020

$$
\mathrm{xh}^{\mathrm{N}}
$$

Key Words: 340 Facility, Retention Process Sewer, Project W353, Diverter Station, Acceptance Test Procedure, Operability Test Procedure

Abstract: This test report includes the results of acceptance and operability testing of the 327 building diverter station. The test included steps for flushing, calibrating, and operating the system on backup power.

\footnotetext{
TRADEMARK DISCLAIMER. Reference herein to any specific comercial product, process, or service by trade name, trademark, manufacturer, or otherwise, does not necessarily constitute or imply its endorsement, recommendation, or favoring by the United States Government or any agency thereof or its contractors or subcontractors.

Printed in the United States of America. To obtain copies of this document, contact: WHC/BCS Document Control Services, P.O. Box 1970, Mai Istop H6-08, Richtand HA 99352, Phone (509) 372-2420; Fax (509) 376-4989.
}
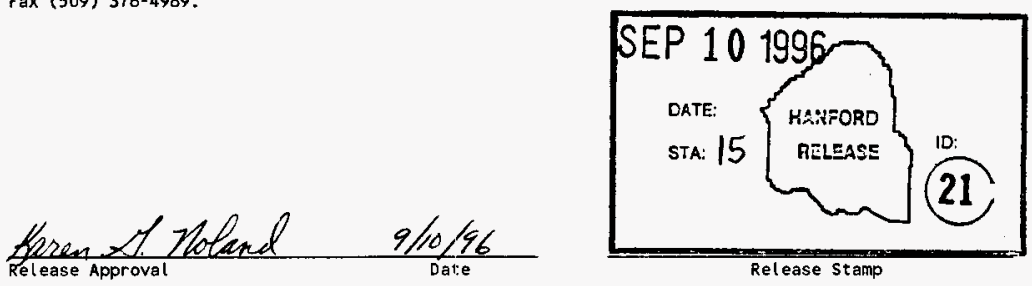

\section{Approved for Public Release}




\begin{tabular}{|c|c|}
\hline WHC-SD-W353-ATR-001 Rev. 0 & Page \\
ACCEPTANCE AND OPERABILITY TEST REPORT FOR THE 327 BUILDING & \\
RETENTION PROCESS SEWER DIVERTER STATION & 1 \\
\hline
\end{tabular}

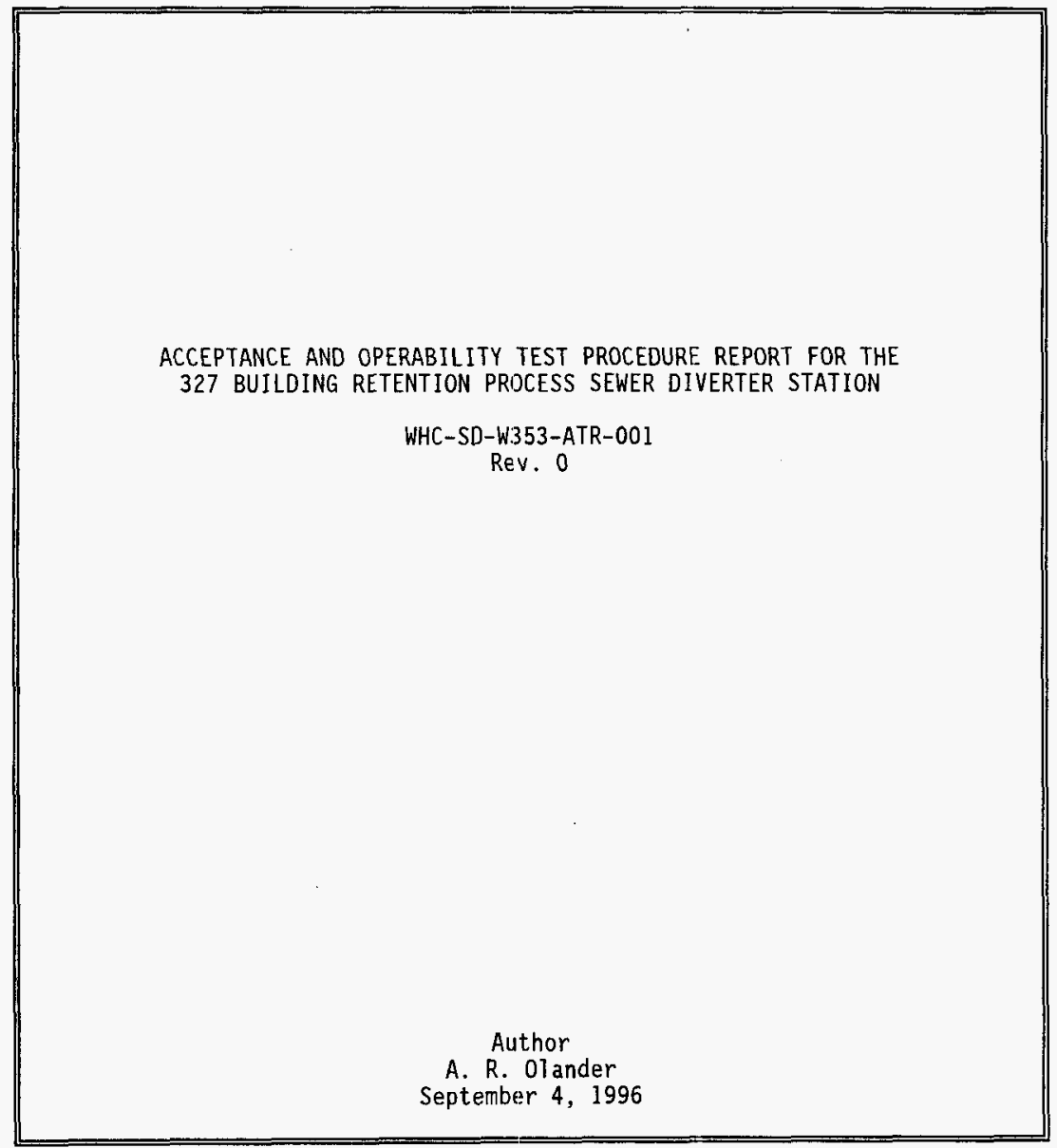




\begin{tabular}{|c|c|}
\hline WHC-SD-W353-ATR-001 ReV. O & Page \\
ACCEPTANCE AND OPERABILITY TEST REPORT FOR THE 327 BUILDING & \\
RETENTION PROCESS SEWER DIVERTER STATION & 2 \\
\hline
\end{tabular}

TABLE OF CONTENTS

1.0 OPERABILITY SUMMARY . . . . . . . . . . . . . . . . . . 3

2.0 TEST CHANGES . . . . . . . . . . . . . . . . . . . . . . . . 3

3.0 SETPOINTS AND POWER . . . . . . . . . . . . . . . . . . . . 3

4.0 RESULTS . . . . . . . . . . . . . . . . . . . . 4

TEST PROCEDURE . . . . . . . . . . . . . . . . . . . . . . . . . . 5 


\begin{tabular}{|c|c|}
\hline WHC-SD-W353-ATR-001 ReV. O & Page \\
ACCEPTANCE AND OPERABILITY TEST REPORT FOR THE 327 BUILDING & 3 \\
RETENTION PROCESS SEWER DIVERTER STATION & \\
\hline
\end{tabular}

\subsection{OPERABILITY SUMMARY}

The system was tested and is functioning as required by the operating organization. The operating goals for the new system are as follows:

- Bypass for alarm response and in-situ calibration.

- Reduce the alarm setpoint from $50,000 \mathrm{pCi} / 1$ to $5,000 \mathrm{pCi} / 1$ with a measurement time of 6 seconds

- Operate on backup power.

Each of these goals was achieved performed during the test.

\subsection{TEST CHANGES}

The were no changes to the test procedure.

\subsection{SETPOINTS AND POWER}

The detector installed in the 327 building is RDA-7AS 107. The calibration setpoints are listed in table 3.1.

Table 3.1 Calibration Setpoints

\begin{tabular}{||l|l|l||}
\hline & Vendor & Actual \\
\hline High Voltage (Volts) & $950-1070$ & 989 \\
\hline Dead Time & $9.97 \mathrm{E}-7$ & $1.0 \mathrm{E}-7$ \\
\hline Source Strength $2 / 26 / 96(\mathrm{pCi} / 1)$ & $1.016 \mathrm{E}+5$ & $1.06 \mathrm{E}+5$ \\
\hline Calibration Constant & $4.42 \mathrm{E}-3$ & $2.24 \mathrm{E}-3$ \\
\hline Background Reading (pCi/1) & $7.97 \mathrm{E}+3-8.17 \mathrm{E}+3$ & $5.32 \mathrm{E}+3$ \\
\hline Check Source Reading $(\mathrm{pC} / 1)$ & $1.25 \mathrm{E}+3-8.3 \mathrm{E}+3$ & $6.0 \mathrm{E}+4$ \\
\hline
\end{tabular}

The breaker to de-energize the system is SF-16. 


\begin{tabular}{|c|c|}
\hline WHC-SD-W353-ATR-001 Rev. O & Page \\
ACCEPTANCE AND OPERABILITY TEST REPORT FOR THE 327 BUILDING & \\
RETENTION PROCESS SEWER DIVERTER STATION & 4 \\
\hline
\end{tabular}

\subsection{RESULTS}

There were no problems with the executing the flushing steps in the procedures, but the water pressure may be too low. The pressure may not be sufficient to remove a heavy sediment from the piping. A more powerful sump pump may need to be purchased for flushing operations .

The calibration source could not be inserted on the first attempt. The detector spool piece has a threaded and welded flange. The source must be inserted into threaded flange side. The test was postponed until the detector was re-oriented. Even with proper orientation the source was difficult to insert. Some possible corrections to improve the fit are to grind the weld fillets smooth, hone the counting chamber, and lubricate the volume source.

The diverter valve relay has an adjustable timer. The timer can be set from 0 to 30 minutes. Attempts were made to set the timer between $1 / 2$ and 1 minute.

The system operated normally when the power cord was unplugged. There were no interruptions in the moritoring or diversion capability when the system was operating off of the battery supply. 


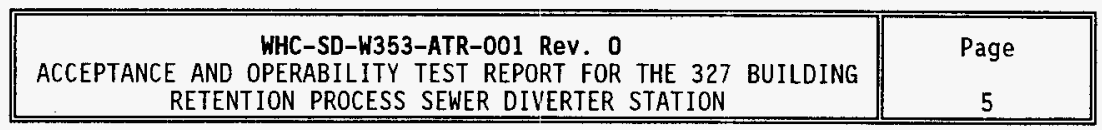

TEST PROCEDURE 
WHC-SD-H/353-ATP-001

\section{Author}

A. R. Olander

April 10, 1996 


\begin{tabular}{|c|c|}
\hline $\begin{array}{l}\text { WHC-SD-W353-ATR-001, Rev. } 0 \\
\text { ACCEPTANCE AND OPERABILITY TEST PROCEDURE FOR THE } 327 \\
\text { BUILDING RETENTION PROCESS SEWER DIVERTER STATION }\end{array}$ & $\begin{array}{c}\text { Page } \\
7\end{array}$ \\
\hline
\end{tabular}

\section{TABLE OF CONTENTS}

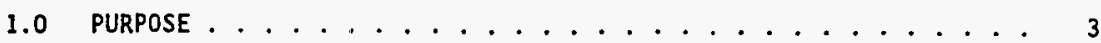

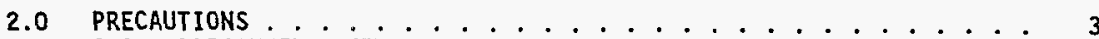

2.1 PERSONNEL SAFETY $\ldots \ldots \ldots$

2.2 PLANT PRECAUTIONS . . . . . . . . . . 3

3.0 ADMINISTRATION ...................... . . 4

3.1 WHC TEST ENGINEER . . . . . . . . . . . . . 4

3.2 HHC OPERATORS . . . . . . . . . . . 4

3.3 PNNL OPERATORS . . . . . . . . . . . . . . 4

3.4 WHC INSTRUMENT TECHNICIAN . . . . . . . . . . 4

3.5 PNNL RADIATION CONTROL TECHNICIANS ......... 5

3.6 KEH CONSTRUCTION FORCES . . . . . . . . . 5

3.7 CHANGES . . . . . . . . . . . . . . 5

3.8 PROCEDURE SEQUENCE $\ldots \ldots \ldots \ldots$

3.9 EXCEPTIONS . . . . . . . . . . . . . . . . . . . 5

3.10 SIGNATURES $\ldots \ldots \ldots$

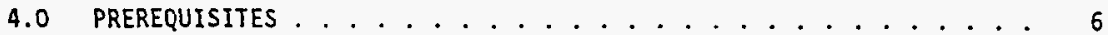

5.0 EQUIPMENT AND SUPPLIES $\ldots \ldots \ldots \ldots \ldots$

6.0 FLUSH AND DRAIN CHECK ................. 6

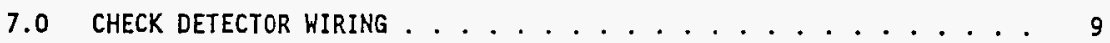

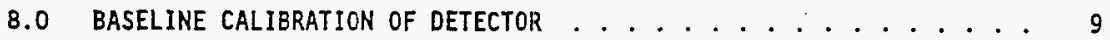

9.0 LEAK CHECK PIPING . . . . . . . . . . . . . . . 11

10.0 VERIFY RPS WATER BACKGROUND LEVEL . . . . . . . . . . . 13

11.0 FULL SYSTEM OPERATION CHECK.. . . . . . . . . . . . 13

12.0 FINAL CONDITIONS ......................... 14

APPENDIX A CHANGE INSTRUCTIONS ..................... 16

OTP CHANGE LOG ........................... 17

SOURCE CALIBRATION SHEET $\ldots \ldots \ldots$ 
WHC-SD-W353-ATR-001, Rev. 0

ACCEPTANCE AND OPERABILITY TEST PROCEDURE FOR THE 327

BUILDING RETENTION PROCESS SEWER DIVERTER STATION

Page

\subsection{PURPOSE}

This Acceptance/Operability test procedure (ATP/OTP) verifies the adequacy and operability of the newly installed radiation detectors. The tests are separated into different sections. Section 6.0 contains steps to ensure operators will be able to flush and drain the piping. Section 7.0 will ensure the detector and UPS have been correctly installed. Section 8.0 provides step for field calibration of the detector. Section 9.0 will utilize the sump pumps to pressurize the piping and check for leaks. The background radiation levels are recorded in section 10.0. Section 11.0 is a full system check. The steps necessary to return the system to a standby condition are listed in section 12.0 .

\subsection{PRECAUTIONS}

\subsection{PERSONNEL SAFETY}

2.1.1 There is a potential for contamination in the retention process sewer (RPS) piping. Follow the requirements of the Radiation Work Permit (RWP).

2.1.2 Air will be used to blow potentially contaminated water from the piping. The air supply must be regulated for contamination control and to ensure operators are not exposed to excessive air pressure.

2.1.3 Due to ventilation fan noise hearing protection is required in the basement of the 327 building.

\subsection{PLANT PRECAUTIONS}

2.2.1 Discharges will be sent from the 327 building to both the 307 basins and 340 vault tanks. Before sending waste to the vault tanks operators working at 340 must be notified to ensure there is no work in proximity to the RLWS piping.

2.2.2 To ensure 327 building operations are not disrupted, air and water supply systems must be secured at the conclusion of each test session.

2.2.3 Clean up all spills as soon as practicable. If unable to be immediately cleaned up, post a sign near the spill to warn personnel. 


\begin{tabular}{|c|c|}
\hline WHC-SD-W353-ATR-001, ReV 0 & Page \\
ACCEPTANCE AND OPERABILITY TEST PROCEDURE FOR THE 327 & 9 \\
BUILDING RETENTION PROCESS SEWER DIVERTER STATION & 9 \\
\hline
\end{tabular}

\subsection{ADMINISTRATION}

\subsection{WHC TEST ENGINEER}

3.1.1 The test engineer must be a certified 340 cognizant engineer.

3.1.2 The test engineer may make minor changes to the test procedure. Such changes must adhere to the following guidelines.

a. Change does not adversely impact test results or expected outcome.

b. Change does not affect personnel safety. ANY personnel related safety changes MUST be approved by the test engineer and a safety representative. Such approval MUST be obtained even if the change appears to improve personnel safety.

c. Change does not affect plant or equipment safety.

\subsection{WHC OPERATORS}

3.2.1 The 340 operators are to certified 340 systems operators.

3.2.2 The operators will take direction from the Test Engineer.

\subsection{PNNL OPERATORS}

PNNL operators will be required to operate the sump pumps and supply air as requested by WHC operators. The operators must be qualified to use 327 building systems.

\subsection{WHC INSTRUMENT TECHNICIAN}

Instrument technicians will be required to calibrate the detector using a vendor supplied source. The technicians must have previous diverter station system maintenance experience. 


\begin{tabular}{|c|c|}
\hline WHC-SD-W353-ATR-001, Rev. 0 & Page \\
ACCEPTANCE AND OPERABILITY TEST PROCEDURE FOR THE 327 & 10 \\
BUILDING RETENTION PROCESS SEWER DIVERTER STATION & \\
\hline
\end{tabular}

\subsection{PNNL RADIATION CONTROL TECHNICIANS}

Radiation control technicians will be required to establish initial conditions and monitor changes to systems with potential contamination.

\subsection{KEH CONSTRUCTION FORCES}

Construction workers will be required to make changes as necessary to ensure equipment operability. For example some systems may leak when water is introduced. Construction forces will also supply tools and equipment necessary to test the installation (operations will supply the drum and submersible pump).

\subsection{CHANGES}

Changes to the test procedure are made per the instructions contained in appendix $A$.

\subsection{PROCEDURE SEQUENCE}

The OTP sections are written in the recommended sequence. The Test Engineer may deviate from this sequence as conditions allow.

The PREREQUISITES and TEST PREPARATIONS sections must be completed prior to performance of any other sections.

\subsection{EXCEPTIONS}

Test exceptions will not be made during this test.

\subsection{SIGNATURES}

Persons signing or initialing for performance steps certify that they have personally witnessed or performed the step(s) or that they have received a direct report of step completion from test personnel. 


\begin{tabular}{|c|c|c|}
\hline WHC-SD-W353-ATR-001, Rev. 0 \\
ACCEPTANCE AND OPERABILITY TEST PROCEDURE FOR THE 327 & Page \\
BUILDING RETENTION PROCESS SEWER DIVERTER STATION & 11 \\
\hline
\end{tabular}

\subsection{PREREQUISITES}

4.1 The WHC project engineer or delegate declares the installation is complete and is ready for testing.

AR Ohunder f. J. Neely $\frac{4 / 18 / 96}{\text { WHC Project Engineer }}$

4.2 The 327 Building Facility Manager approves the start of testing activities.

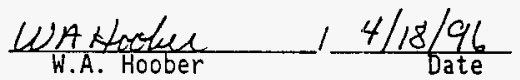

5.0 EQUIPMENT AND SUPPLIES

$\begin{array}{ll}\text { O Open top drum } & \text { o Measuring Tape } \\ \text { - Submersible pump } & \text { o Pressure Regulator } \\ \text { Extension Cord with GFCI } & \text { O Two Hoses } \\ \text { - Hardware to Connect Air Hose to Garden Hose o Volume Source }\end{array}$

\subsection{FLUSH AND DRAIN CHECK}

The purpose of this test is to verify the detector can be flushed and drained. Flushing will be required to remove contaminants that have accumulated in the detector drop leg. Draining the system of liquid will be necessary prior to calibrating the system.

6.1 Verify the following initial valve positions (See Figure 1):

\begin{tabular}{|c|c|}
\hline Valve & POSition \\
\hline Diverter Valve & TO RPS \\
\hline PNNL Hose Connection Valve & CLOSED \\
\hline $340-B P-V-1$ & CLOSED \\
\hline $340-B P-V-2$ & CLOSED \\
\hline $340-B P-V-3$ & OPEN \\
\hline $340-B P-V-4$ & CLOSED \\
\hline $340-C O-V-1$ & CLOSED \\
\hline $340-D R-V-1$ & CLOSED \\
\hline
\end{tabular}




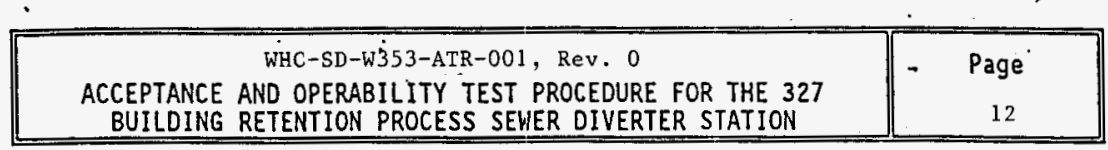

Figure 1: 327 Divert Isometric

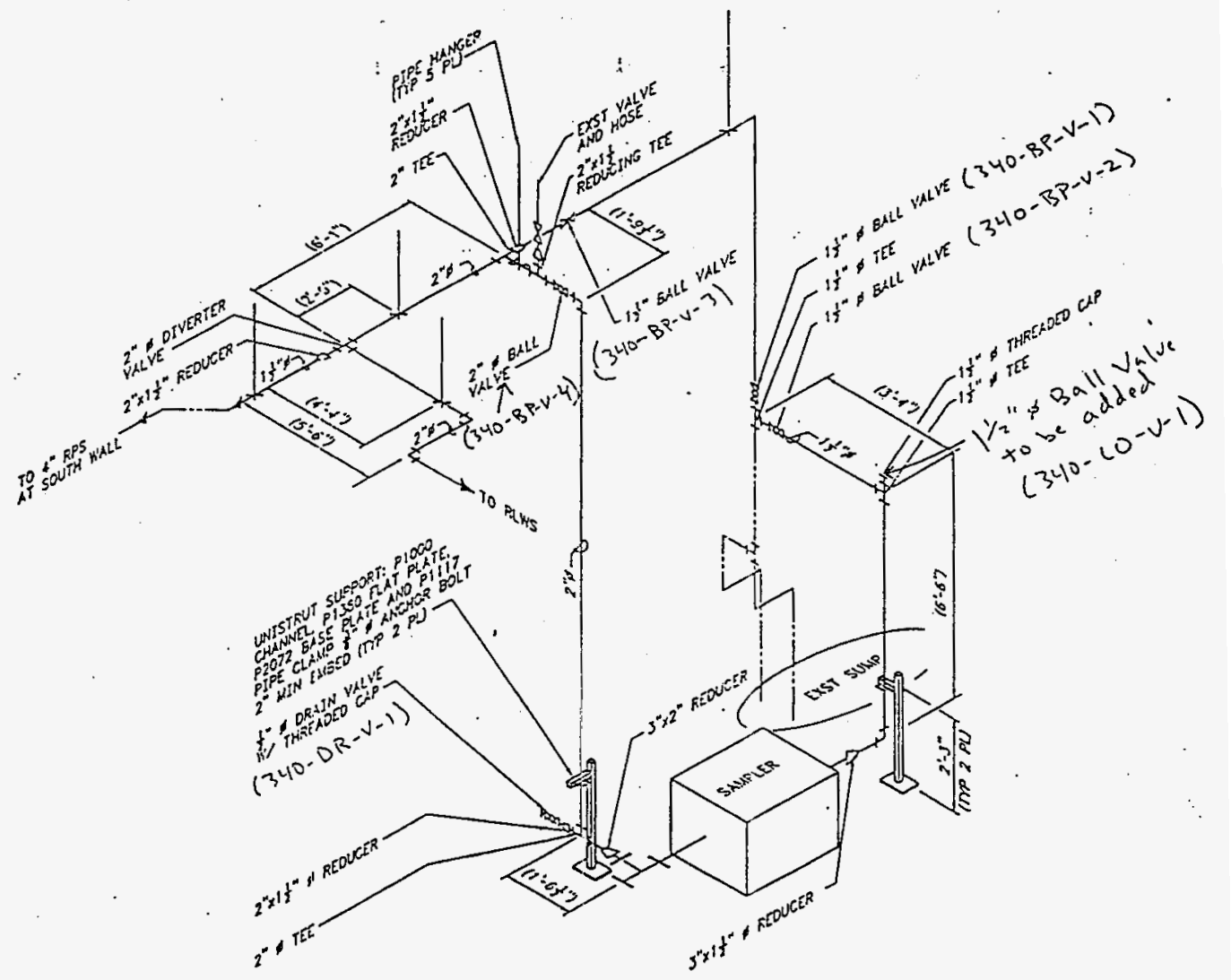

\section{ISOMETRIC}


6.2 Have the PNNL operator verify PNNL pumps switches are in off or manual.

6.3 Position the drum with submersible pump close to $340-\mathrm{CO}-\mathrm{V}-1$.

Verify pump power cord is undamaged, then plug pump into a GFCI.

6.4 Connect pump discharge hose to hose connection at 340-CO-V-1.

6.5 Fill the drum about $75 \%$ full with clean water.

6.6 Open valve $340-C 0-V-1$.

6.7 Start submersible pump.

6.8 Quickly open valve 340-BP-V-4.

6.9 Pump majority of liquid from drum.

6.10 Close valve $340-B P-V-4$.

6.11 Quickly shut off submersible pump.

6.12 Close valve $340-\mathrm{CO}-\mathrm{V}-1$.

6:13 Disconnect pump discharge hose at 340-CO-V-1.

6.14 Connect a hose at $340-D R-V-1$ and route the discharge to the RPS sump.

6.15 Open vaive 340-DR-V-1.

6.16 Open vaive 340-CO-V-1.

6.17 When flow has slowed have the PNNL operator connect an air hose with pressure regulator at $340-\mathrm{CO}-\mathrm{V}-1$ (pressure must be 1 imited to less than 20 psi).

6.18 Have the PNNL operator slowly increase the air flow and blow water out of piping to the RPS sump.

6.19 After the majority of the water has been blown out discontinue the air blow.

6.20 Remove the source insertion blind flange and check piping for water.

Water present? (es)No a comple of gallong mayhe
less a longer blow 


\begin{tabular}{|c|c|}
\hline WHC-SD-W353-ATR-001, Rev, 0 & Page \\
ACCEPTANCE AND OPERABILITY TEST PROCEDURE FOR THE 327 & \\
BUILDING RETENTION PROCESS SEWER DIVERTER STATION & 14 \\
\hline
\end{tabular}

6.21 If water is present inside the piping, wipe dry with rags.

6.22 Consult with the building RCT for rag disposal requirements.

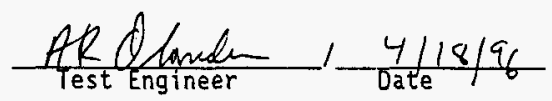

\subsection{CHECK DETECTOR WIRING}

The purpose of this section is to verify the detector has been wired correctly.

7.1 Press the On/Off button on the SRM300. The reading should be approximately $2000 \mathrm{pCi} / 1$.

7.2 Turn on the UPS and then the enclosure's power strip switch. If necessary, press the check source button to retract the Ba-133 check source from the SA-18S. The SRM 300 's reading should go to zero.

7.3 If there are no problems, the interwiring as been correctly done.

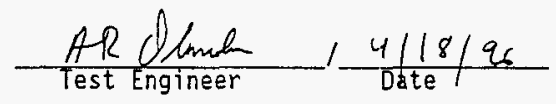

\subsection{BASELINE CALIBRATION OF DETECTOR}

This section provides instructions for gathering background data and performing a baseline calibration of the detector. The 340 and or TEDF control room operator and 327 personnel should be notified about potential 327 alarms. 


\begin{tabular}{|l|c|}
\hline WHC-SD-W353-ATR-001, ReV 0 & Page \\
ACCEPTANCE AND OPERABILITY TEST PROCEDURE FOR THE 327 & \\
BUILDING RETENTION PROCESS SEWER DIVERTER STATION & 15 \\
\hline
\end{tabular}

8.1 Have the instrument technician verify SRM300 settings for the corresponding detector element.

\begin{tabular}{|c|c|c|c|c|}
\hline & RDA.7AS 105 & RDA-7AS 106 & RDA-7AS $107 \quad 327$ & RDA-7AS108 \\
\hline $\begin{array}{l}\text { High Voltsgo } \\
\text { \{Volts\} }\end{array}$ & 1070 & 950 & $950.1070 \& 89$ & 989 \\
\hline Desd Time & $9.97 \mathrm{E} \cdot 7$ & $9.97 E \cdot 7$ & $9.97 \mathrm{E} \cdot 7 \quad 1.0^{-7}$ & 9.97E-7 \\
\hline $\begin{array}{l}\text { Source Strength } \\
2 / 26 / 96(\mathrm{pCi} / 2)\end{array}$ & $1.016 E+5$ & $1.016 E+5$ & $1.016 E+5$ & $1.016 E+5$ \\
\hline $\begin{array}{l}\text { Calibration } \\
\text { Constant }\end{array}$ & $3.81 E-3$ & $3.42 \mathrm{E}-3$ & $4.42 E \cdot 3 \quad 2.24-3$ & $4.42 \mathrm{E}-3$ \\
\hline $\begin{array}{l}\text { Background } \\
\text { Resding (pCi/l) }\end{array}$ & $8.17 E+3$ & $9.7 E+3$ & $\begin{array}{r}7.97 E+3.8 .17 E+3 \\
5.32+3 \\
\end{array}$ & $7.97 \varepsilon+3$ \\
\hline $\begin{array}{l}\text { Check Source } \\
\text { Reading (pCi/l) }\end{array}$ & $1.25 E+3$ & $8.3 E+4$ & $1.25 \varepsilon+3-8.3 E+4$ & $6.38 E+3$ \\
\hline
\end{tabular}

8.2 Set background to o.' / approximutely 0

8.3 Set dead time to $1.0 E-7$ and units to $\mathrm{pCi} / 1$.

8.4 Decay correct the source (active volume $1556 \mathrm{cc}$ with $27 \mathrm{pCi} / \mathrm{dps}$ ) and record below (see source calibration sheet in Appendix A).

$$
\begin{aligned}
A=A_{0}(0.5)^{t / T}{ }_{1 / 2} & A_{0}=\text { Initial Activity }=6195 \mathrm{dps} \\
t_{1 / 2} & =\text { Half Life of } C s-137=30.17 \text { years }
\end{aligned}
$$

$$
\text { Source Strength }=106755^{-} \quad \mathrm{pCi} / 1 \quad 106,755 \mathrm{pc} / \mathrm{e}
$$

8.5 Set the count time to 6 seconds.

8.6 Remove the end flange from the tee and attach a strong cord to the source's eyelet. Push the source into the tee then into the spool. The source may have to be rotated if it binds on insertion.

8.7 With a measuring stick verify that the source is extending $1.25 \mathrm{~cm}$ $\left(0.5^{\prime \prime}\right)$ out of the SA-18S main shield. The SA-18S shield is 43.5 $\mathrm{cm}$ (17.4") long and the source is $44.1 \mathrm{~cm}$ (17.63") long with a $1.25 \mathrm{~cm}\left(0.5^{\prime \prime}\right)$ thick end plug. Measure and record the flange to source distance.

Flange to Source Distance $=15.5^{\prime \prime}$ 
WHC-SD-W353-ATR-001, Rev . 0

ACCEPTANCE AND OPERABILITY TEST PROCEDURE FOR THE 327

BUILDING RETENTION PROCESS SEWER DIVERTER STATION

Page

16

8.8 Adjust calibration constant until it reads the decay corrected $\mathrm{pC} \mathrm{C} / \mathrm{l}$ value calculated in step 8.4 (the calibration constant will be in $\operatorname{cps} / \mathrm{pCi} / 1)$.

8.9 Pull the source out using the cord and make sure it does not bind as it is extracted.

8.10 Adjust background until it reads an average value of zero $\mathrm{pCi} / 1$.

The back ground determined at Eberline was most likely higher than Hanford. The SRM300 will over subtract giving zero for the average number at Hanford if no appreciable activity is in the water.

8.11 Repeat steps 8.8 through 8.11 until the calibration constant gives the true net $\mathrm{pCi} / \mathrm{l}$ as a typical zero and span routine on an analog instrument would require. The net value will be a conservative number since the apparent source activity does not completely fill the spool as a solution would do.

8.12 Set aiarm setpoint to $5,000 \mathrm{pCi} / 1$.

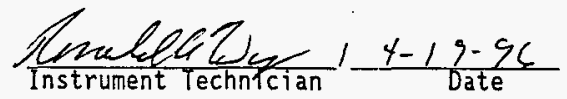

\subsection{LEAK CHECK PIPING}

The objective of this section is to pressure test the newly installed piping. The test relies on the RPS sump pumps to pressurize the detector and piping to verify the system is free from leaks.

9.1 Remove tag (if required) and activate diverter valve. 


\begin{tabular}{|c|c|}
\hline WHC-SD-W353-ATR-001, Rev. 0 & Page \\
ACCEPTANCE AND OPERABILITY TEST PROCEDURE FOR THE 327 & 17 \\
BUILDING RETENTION PROCESS SEWER DIVERTER STATION & 17 \\
\hline
\end{tabular}

9.2 Verify the following initial valve line up.

\begin{tabular}{|c|c|}
\hline Valve & Position \\
\hline Diverter Valve & TO RPS \\
\hline PNNL Hose Connection Valve & CLOSED \\
\hline $340-B P-V-1$ & CLOSED \\
\hline $340-B P-V-2$ & OPEN \\
\hline $340-B P-V-3$ & OPEN \\
\hline $340-B P-V-4$ & OPEN \\
\hline $340-C O-V-1$ & CLOSED \\
\hline $340-D R-V-1$ & CLOSED \\
\hline
\end{tabular}

9.3 Connect a hose to the building water supply.

9.4 Fill sump about $75 \%$ full with clean water.

Note: Do not continuously flow water into the sump. Efforts should be made to minimize the quantity of water used during testing.

9.5 Have PNNL operator start sump pump.

9.6 Check system for leaks.

9.7 Have construction forces el iminate leaks as required.

9.8 If no leaks are evident, slowly throttle valve $340-B P-V-4$ to create backpressure in the system (do not close the valve completely). Tighten to eliminate leaks as required.

9.9 When this section is completed then sign below

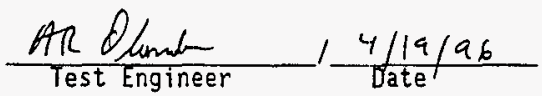




\begin{tabular}{|c|c|c|}
\hline WHC-SD-W353-ATR-001, Rev. O & Page \\
ACCEPTANCE AND OPERABILITY TEST PROCEDURE FOR THE 327 & 18 \\
BUILDING RETENTION PROCESS SEWER DIVERTER STATION & 18 STION \\
\hline
\end{tabular}

\subsection{VERIFY RPS WATER BACKGROUND LEVEL}

The objective of this section is to determine the background radiation reading with the pipe full of RPS water.

10.1 Switch the SRM300 to background mode and record value below.

$$
\text { Background }=300^{-} \mathrm{pCi} / 1
$$

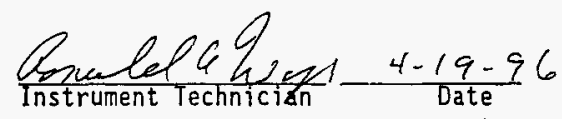

\subsection{FULL SYSTEM OPERATION CHECK}

The objective of this section is to demonstrate the system will detect radiation, alarm, and divert the flow into the RLWS system. The test is run under power failure conditions to verify the UPS performance.

11.1 Verify the UPS is in auto mode (if not, press CONTROL, 2, and then press ENTER twice.

11.2 Switch off power to the UPS to simulate a power outage.

11.3 Activate the check source by pressing the check source button. The check source will have to be pressed continuously until a reading is obtained.

11.4 Press the speaker button to acknowledge and silence the alarm.

11.5 Verify the diverter valve cycled and moved to direct flow to the RLWS.

11.6 Note the displayed reading and record below after releasing the pushbutton.

Check Source Value $5 k-6 k \quad p[i / 1$ as it retructs level

11.7 Retract the check source by releasing the button. goes to $10 \mathrm{k}$

11.8 Call 340 or TEDF to verify the 327 diverter alarm was received and has cleared. Verify that 327 received a local alarm and that the a] arm was received on the FMCS.

11.9 Have the PNNL operator switch the pump control to automatic. 
WHC-SD-W353-ATR-001, Rev. 0

ACCEPTANCE AND OPERABILITY TEST PROCEDURE FOR THE 327

BUILDING RETENTION PROCESS SEWER DIVERTER STATION
Page

19

11.10 Add water to the sump to initiate an automatic pump out.

11.11 As water is flowing from the sump note the detector display output. Record the maximum ievel displayed.

Maximum reading during pump out $=500 \quad \mathrm{pCi} / 1$

$\frac{\text { AR dhoh }}{\text { Test Engineer }} / \frac{4 / 14 / 96}{\text { Date }}$

\subsection{FINAL CONDITIONS}

The objective of this section is to restore the system to the pretesting condition. This section will be performed at the end of each test period and when all OTP testing has been concluded.

12.1 Position the valve as listed below:

\begin{tabular}{|c|c|}
\hline Valve & Position \\
\hline Diverter Valve & TO RLWS \\
\hline PNNL Hose Connection Valve & CLOSED \\
\hline $340-B P-V-1$ & OPEN \\
\hline $340-B P-V-2$ & CLOSED \\
\hline $340-B P-V-3$ & OPEN \\
\hline $340-B P-V-4$ & CLOSED \\
\hline $340-C O-V-1$ & CLOSED \\
\hline $340-D R-V-1$ & CLOSED \\
\hline
\end{tabular}

12.2 If necessary tag diverter valve ensure valve is not operated.

12.3 Install a caution tag to prevent diverter valve operation.

12.4 Verify that the sump pump controls are off or in manual.

12.5 Leave UPS in auto.

12.6 Leave SRM300 in the on position. 
WHC-SD-W353-ATR-001, Rev . 0

ACCEPTANCE AND OPERABILITY TEST PROCEDURE FOR THE 327

Page

BUILDING RETENTION PROCESS SEWER DIVERTER STATION

20

12.7 Empty residual liquid from drum.

12.8 Store 340 operations owned hoses and equipment in drum for future flushing operations in 327.

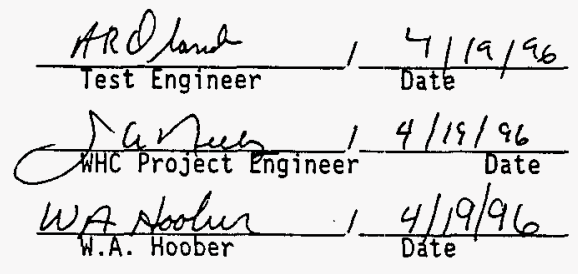




\begin{tabular}{|c|c|c|}
\hline WHC-SD-W353-ATR-001, Rev. 0 & Page \\
ACCEPTANCE AND OPERABILITY TEST PROCEDURE FOR THE 327 & \\
BUILDING RETENTION PROCESS SEWER DIVERTER STATION & 21 \\
\hline
\end{tabular}

\section{APPENDIX A CHANGE INSTRUCTIONS}

This appendix 1 ists all the steps necessary to make changes to the OTP. The test director or engineer are authorized to make changes.

1.0 Obtain test engineer approval for all changes that do not have an "NA" approval designator. If in doubt then confer with the test engineer manager.

NOTE: For other than "NA" designators an ECN will need to be issued.

2.0. Read "minor changes" in the administrative section under the test engineer description. Verify the test director does not need to be notified for any of the types of changes listed.

3.0 . For all changes enter the next sequential number (starting with 001) in the change log (next page) along with a brief description.

4.0 If the change is "minor" in scope then make the change using pen and ink or retype the entire page. Initial/date the change or sign/date the top of a retyped page near the header. Enter the change number next to your initials or signature.

5.0 If a change requires an ECN then the ECN will describe how to make the change. 


\begin{tabular}{|c|c|}
\hline $\begin{array}{l}\text { WHC-SD-W353-ATR-001, Rev. } 0 \\
\text { ACCEPTANCE AND OPERABILITY TEST PROCEDURE FOR THE } 327 \\
\text { BUILDING RETENTION PROCESS SEWER DIVERTER STATION }\end{array}$ & $\begin{array}{c}\text { Page } \\
22\end{array}$ \\
\hline
\end{tabular}

\begin{tabular}{|l|l|l|}
\hline \multicolumn{1}{|c|}{ OTP CHANGE LOG } \\
\hline $\begin{array}{l}\text { CHANGE } \\
\text { NUMBER }\end{array}$ & & \\
\hline & OTP CHANGE LOG \\
\hline & \\
\hline & \\
\hline & \\
\hline & \\
\hline & \\
\hline & \\
\hline & \\
\hline & \\
\hline & \\
\hline & \\
\hline & \\
\hline & \\
\hline
\end{tabular}


WHC-SD-W353-ATR-001, Rev. D

ACCEPTANCE AND OPERABILITY TEST PROCEDURE FOR THE 327 BUILDING RETENTION PROCESS SEWER DIVERTER STATION

\section{SOURCE CALIBRATION SHEET}

$\mathbb{\Delta}_{\text {aNartics }}$

Ansticaline.

is50 Se aboud industrinl Bouknot

Afluate Crofia ;0:15

+04 32.56i7

\section{CERTIFICATE OF CALIBRATION :}

Standard Radionuclide Source

$515,20-404$

Cs-137 solid in Plestic custom source Holder

This standerd radionuclice source hes prepared using an allquot measured gravinetrically from a calibrated master liquid zedicnuclide solution source. The mester source vas calibrated in en ion chenber that wes calibrated by the National zhysical Leboracory, Teddington, U.K., and is directly treceable to netional stancards. ANALYTICS maintaiss traceability to the National Irstitute of Standards and Technology through Measurements assurance Programs as lescribed in USNRC Reg. Guide 4.25, Revision 1.

Redionuclide purity and calibration were checked using a germanium gamia spectroneter system. The nuclear decay rate and assey dete for this source are giver below.

U.S. Patent 4,430,258; U.K. Petent G32,149,194B; CA. Patent $1,196,775$. Density of solid matrix $1.15 \mathrm{~g} / \mathrm{cc}$.

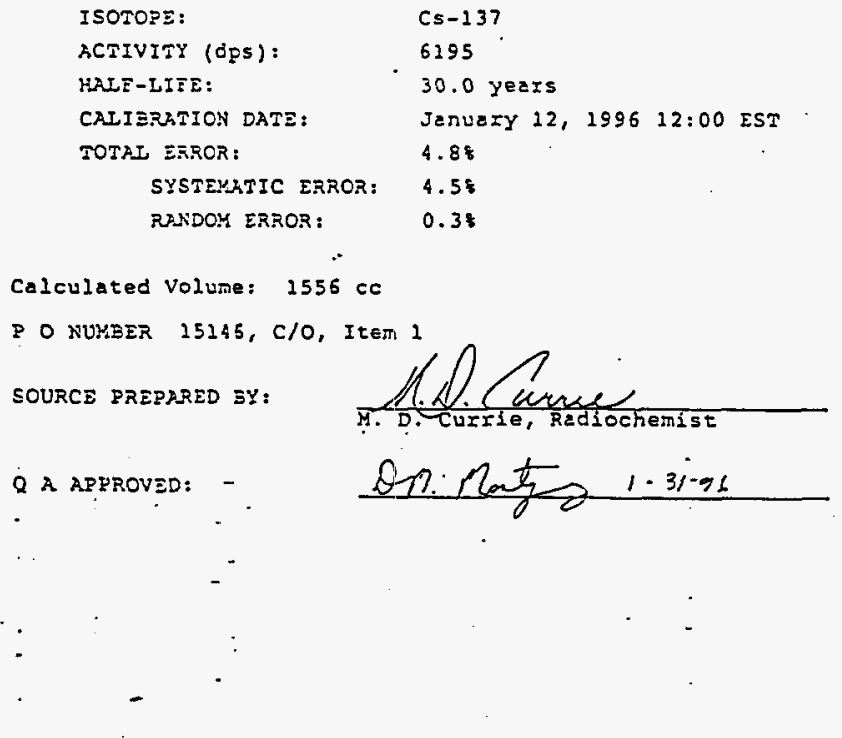

